\title{
PENERAPAN TEKNIK ROLE PLAYING UNTUK MENINGKATKAN SELF CONFIDENCE SISWA KELAS X E SMA NEGERI 5 BANJARMASIN
}

\author{
Wiyono \\ Wiyono5@gmail.com \\ SMA Negeri 5 Banjarmasin
}

\begin{abstract}
Self Self Confident is an important factor that can affect the life of a successful person, a person who self confidence low in students including dared not ask questions or concerns during the learning process, feel the physical form is not perfect of friends to another, do not dare to appear in front of the class, talking nervously if the front of the crowd, low socioeconomic status, and have friends who are limited so that the impact on their social interactions, eg impact in their social interactions decreased academic achievement, insecure, often aloof and reserved. Based on the above problems, the researchers are interested in doing research, entitled Implementation Techniques for Increasing Self Confidence Roleplaying $10^{\text {th }}$ E Grade Students Of Senior High School 5 Banjarmasin.

This type of research is quantitative research with experimental research design. This place in Senior High School 5 Banjarmasin whose population the $10^{\text {th }} \mathrm{E}$ grade students numbering 34 students. Sampling technique used in this study is a sampling technique is purposive sampling with the number of 12 students.

Data were analyzed using $t$ test and demonstrate $t_{\text {hit }} 51.83>t_{\text {tab }} 2,228$ with a $95 \%$ confidence level. Thus showing that the "role playing techniques are effective in improving students' self confidence, which is marked by the increasing scale of student's self confidence.
\end{abstract}

Kata Kunci : Teknik Roleplaying, Self Confidence

\section{PENDAHULUAN}

Self confidence merupakan faktor penting yang dapat mempengaruhi kehidupan sukses seseorang, karena self confidence yang mantap akan menimbulkan motivasi dan semangat yang tinggi pada jiwa seseorang.

Menurut (Hakim, Thursan. 2005: 8) orang yang memiliki self confidence rendah yaitu: 1) mudah cemas dalam menghadapi persoalan dengan tingkat kesulitan tertentu, 2) memiliki kelemahan atau kekurangan dari segi mental, fisik, sosial atau ekonomi, 3) sulit menetralisasi timbulnya ketegangan dalam suatu situasi, 4) gugup dan kadang- kadang bicara gagap, 5) sulit menerima realita diri, 6) pesimis, dan 7) menilai dirinya tidak mampu. 
Dari berbagai cara yang bisa dilakukan oleh konselor sekolah dalam mengatasi permasalahan tersebut yaitu dengan cara menggunakan teknik role playing dan sosiodrama, namun teknik yang lebih tepat untuk meningktkan self confidence yaitu teknik role playing. Adapun kelebihan teknik role playing yaitu menurut Sanjaya, Wina (2009:160) a) bermain peran dapat dijadikan bekal bagi siswa dalam menghadapi situasi yang sebenarnya kelak, baik dalam kehidupan keluarga, masyarakat, maupun menghadapi dunia kerja. b) bermain peran dapat mengembangkan kreativitas siswa, karena melalui simulasi siswa diberi kesempatan untuk memainkan peranan sesuai topik yang diperankan. c) bermain peran dapat memupuk keberanian dan percaya diri siswa. d) memperkaya pengetahuan, sikap, dan keterampilan yang diperlukan dalam menghadapi berbagai situasi sosial yang problematic, dan e) bermain peran dapat meningkatkan gairah siswa dalam proses pembelajaran.

Melalui Teknik Role Playing dapat melatih keberanian siswa dalam mengekspresikan prilaku-prilaku tertentu dengan bermain peran, latihan, dan sosial modeling atau meniru modelmodel sosial. Dari hasil observasi terhadap siswa SMA Negeri 5 Banjarmasin masih banyak siswa yang menunjukkan indikator self confidence rendah diantaranya tidak berani mengajukan pertanyaan atau pendapat pada saat proses belajar, tidak berani tampil didepan kelas, berbicara gugup kalau didepan orang banyak, merasa bentuk fisiknya tidak sempurna dari teman-teman yang lain, status sosial ekonomi yang rendah, dan memiliki teman yang terbatas.

Untuk mengatasi permasalahan tersebut maka digunakan teknik Role Playing untuk meningkatkan Self Confidence siswa. Didukung oleh hasil penelitian (Widiawati, Ririn. 2009 : 1) dari hasil penelitian tersebut terbukti bahwa teknik role playing dapat meningkatkan motivasi belajar siswa dan hasil penelitian oleh (Seran, Eliana Yunitha, 2010:1) teknik role playing signifikan dalam meningkatkan kemampuan berfikir kritis dan kepekaan sosial siswa.

Tujuan penelitian ini adalah untuk mengetahui gambaran Self Confidence siswa kelas $\mathrm{X}$ E di SMA Negeri 5 Banjarmasin sebelum/pra diberikan teknik Role Play, mengetahui gambaran Self Confidence siswa kelas X E di SMA Negeri 5 Banjarmasin setelah/post 
diberikan teknik Role Playing, dan mengetahui keefektifan teknik Role Playing dalam meningkatkan Self Confidence siswa kelas X E di SMA Negeri 5 Banjarmasin.

\section{METODE PENELITIAN}

\section{A. Rancangan Jenis Penelitian}

Penelitian kuantitatif ini dilakukan dengan rancangan penelitian eksperimen. Penelitian eksperimen merupakan penelitian yang digunakan untuk mencari pengaruh perlakuan tertentu terhadap orang lain dalam kondisi yang terkendalikan. (Sugiyono, 2011: 107). Adapun populasi dari penelitian ini adalah siswa kelas XE SMA Negeri 5 Banjarmasin tahun ajaran 2014-2015. Berdasarkan populasi siswa kelas X E yang berjumlah 34. Pada bulan Desember 2014 dipilih sampel dengan membagikan skala pengukuran self confidence.

Untuk menentukan sampel penelitian, dengan pertimbangan tertentu sesuai dengan inklusi sebagai berikut:

a. Melaksanakan pretest dengan membagikan skala pengukuran self confidence kepada siswa kelas XE.

b. Dari hasil pengukuran skala self confidence siswa kelas XE, siswa yang tingkat self confidence paling rendah akan dijadikan sampel.

c. Berdasarkan dari hasil pengukuran skala self confidence diperoleh sampel sampel tersebut sebanyak 12 orang, yang kemudian akan dilakukan wawancara.

d. Berdasarkan hasil dari wawancara terhadap seluruh sampel 12 orang bersedia untuk diberikan Teknik Role Playing.

e. Mengambil sejumlah siswa untuk diberikan konseling yaitu sampel yang diberi perlakuan dan sampel yang tidak diberi perlakuan, jadi ada 6 sampel yang akan diberi perlakuan dan ada 6 sampel yang tidak diberikan perlakuan.

\section{B. Teknik Penarikan Sampel}

Teknik sampel yang digunakan dalam penelitian ini adalah teknik penarikan sampel secara Purposive Sampling. Purposive Sampling adalah teknik penentun sampel dengan pertimbangan tertentu atau bertujuan yaitu dalam penelitian ini siswa yang mempunyai self confidence rendah. 


\section{Pelaksanaan Penelitian}

a. Tahap Pre-Test

Dalam tahap ini peneliti melakukan pengukuran dengan membagikan instrumen skala Self Confidence kepada kelas XE sebelum perlakuan.

b. Tahap Eksperimen/Tahap Konseling 1) Tahap I Pembukaan ( Pengenalan,Pelibatan dan Pemasukan diri) Tahap Pembukaan dilaksanakan dalam waktu -/+ 10 menit.

a) Tahap pembukaan ini merupakan sesi perkenalan.

b) Konselor membangun hubungan pribadi dengan kelompok konseli. Konselor menjelaskan peran dia sebagai konselor dan siswa sebagai klien. Konselor memberitahukan asas-asas dan kode etik yang dipegang konselor dalam proses konseling.

c) Pada tahap ini konselor berusaha untuk membentuk suatu hubungan (rapport) yang baik dengan siswa dengan menunjukkan perilaku attending, sehingga hal ini dapat membantu konselor untuk menumbuhkan rasa kepercayaan siswa kepada konselor.

d) Konselor dan siswa membuat kesepakatan waktu yaitu lama waktu yang akan ditempuh pada setiap sesi konseling yang akan dilaksanakan (sekitar 45 menit).

2) Tahap II (Penjelasan Masalah) Tahap penjelasan masalah dilaksanakan dalam waktu -/+ 10 menit

Konselor menjelaskan tujuan dan materi diskusi "Self Confidence”.

3) Tahap III (Penggalian Latar Belakang Masalah) Tahap penggalian latar belakang masalah dilaksanakan dalam waktu -/+ 15 menit

Konselor mempersilahkan masing-masing konseli untuk mengemukakan masalahnya yang berhubungan dengan Self Confidence.

a) Masing-masing konseli mengutarakan pemikiran dan perasaanya berkaitan dengan Self Confidence

b) Siswa saling mendengarkan ungkapan teman-teman serta menaggapinya. 
c) Konselor mendengarkan ungkapan masing-masing konseli dengan penuh perhatian dan membuat ringkasan permasalahan dan mengusulkan suatu rumusan umum, dan mengkongkretkan materi diskusi. Menentukan pendekatan yang sebaiknya diterapkan.

d) Setelah konselor mengidentifikasi masalah dan menggali latar belakang terjadinya masalah pada siswa, konselor kemudian menawarkan beberapa alternatif yang diperuntukkan membantu masalah belajar yang dihadapi siswa.

e) Salah satu alternatif pemecahan masalah yang ditawarkan konselor kepada siswa yaitu teknik Role Playing.

f) Konselor pada tahap ini menjelaskan mengenai teknik Role Playing.

4) Tahap IV (Penyelesaian Masalah) Tahap penyelesaian masalah dilaksanakan dalam waktu -/+ 25 menit a) Konseli bersama kelompoknya menyusun atau menyiapkan skenario yang akan ditampilkan.

1) Menentukan drama/peranan apa yang akan dibawakan diberi waktu maksimal 5 menit

2) Membagi tokoh peran yang akan dibawakan

3) Diberi waktu minimal 10 menit untuk bermain peran

b) Konselor memanggil tiap kelompok untuk melakonkan skenario yang sudah dipersiapkan

c) Kelompok konseli bermain peran/Role Playing memerankan skenario yang disiapkan

5) Tahap V (Kesimpulan dan Penutup) Tahap kesimpulan dan penutup dilaksanakan dalam waktu -/+ 15 menit

a) Konseli mengungkapkan pengalamannya selama proses konseling

b) Konseli mengungkapkan kritik dan tanggapan setelah melakukan simulasi

c) Konselor melakukan evaluasi terhadap proses konseling 
Volume 4 Nomor 1, April 2018

dengan memepersilahkan

konseli mengungkapkan

perasaan puas mengenai hal-

hal apa dan perasaan tidak puas tentang hal- hal apa.

d) Konselor

penguatan/sanjungan

menumbuhkan

semangat

kepada siswa untuk berani

bertindak.

e) Konselor

menetapkan

pertemuan kedua dalam rangka

tindak lanjut 3 hari sesudah pertemuan pertama dilakukan.

f) Konselor menutup konseling dan bersama-sama bernyanyi.

\section{Teknik Pengolahan dan Analisis Data}

Setelah pemberian perlakuan yaitu konseling dengan menggunakan teknik Role Playing, dilakukan pengukuran kembali dengan menggunakan skala Self Confidence, yang bertujuan untuk mengetahui apakah ada perubahan tingkat Self Confidence pada diri siswa sebelum diberi perlakuan.

Pengolahan prosentasi skor self confidence dapat dimasukkan kedalam kategori: rendah, sedang, tinggi, dan sangat tinggi, digunakan kriteria perhitungan sebagai berikut:

1. Presentasi maksimal

$$
\begin{aligned}
& : \quad \frac{35 \times 4}{35 \times 4} \times 100 \%=11 \\
& : \quad \frac{35 \times 1}{35 \times 4} \times 100 \%=
\end{aligned}
$$

2. Presentasi minimal

3. Rentang $: 100 \%-25 \%=75 \%$

4. Panjang kelas interval $: 75 \%: 4=18,75 \%$

Dengan panjang interval $18,75 \%$ dan presentasi minimal $25 \%$ maka dapat dibuat kriteria sebagai berikut:

Tabel 1

Interpretasi Prosentasi Skor Self Confidence

\begin{tabular}{|l|l|l|}
\hline No & Interval (dalam \%) & Katagori \\
\hline 1. & $25-43,37$ & Rendah \\
\hline 2. & $43,76-62,51$ & Sedang \\
\hline 3. & $62,52-81,27$ & Tinggi \\
\hline 4. & $81,28-100$ & Sangat Tinggi \\
\hline
\end{tabular}


Data yang diperoleh kemudian dianalisis dengan menggunakan :

a. Analisis t-test. (Sugiyono, $2011: 273$ ).

$$
\mathrm{t}=\frac{\overline{\mathrm{X}}_{1}-\overline{\mathrm{X}}_{2}}{\sqrt{\frac{\left(\mathrm{n}_{1}-1\right) \mathrm{s}_{1}^{2}+\left(\mathrm{n}_{2}-1\right) \mathrm{s}_{2}^{2}}{\mathrm{n}_{1}+\mathrm{n}_{2}-2}\left(\frac{1}{\mathrm{n}_{1}}+\frac{1}{\mathrm{n}_{2}}\right)}}
$$

Keterangan :

$\mathrm{t} \quad=$ Koefisien $\mathrm{t}$-studen yang dicari

$\overline{\mathrm{X}}_{1} \quad=$ Rata-rata nilai pada kelompok I

$\overline{\mathrm{X}}_{2} \quad=$ Rata-rata nilai pada kelompok II

$\mathrm{n}_{1}=$ Jumlah subjek pada kelompok I

$\mathrm{n}_{2}$ = Jumlah subjek pada kelompok II

$\mathrm{s}_{1}^{2}=$ Varian Kelompok I

$\mathrm{s}_{2}^{2}=$ Varian Kelompok II

\section{HASIL PENELITIAN DAN PEMBAHASAN}

Gambaran perbedaan hasil pre test dan post test self confidence dapat dilihat pada diagram batang sebagai berikut:

\section{Gambar 1}

Diagram Batang Perbedaan Pre Test dan Post test Kelompok Treatment

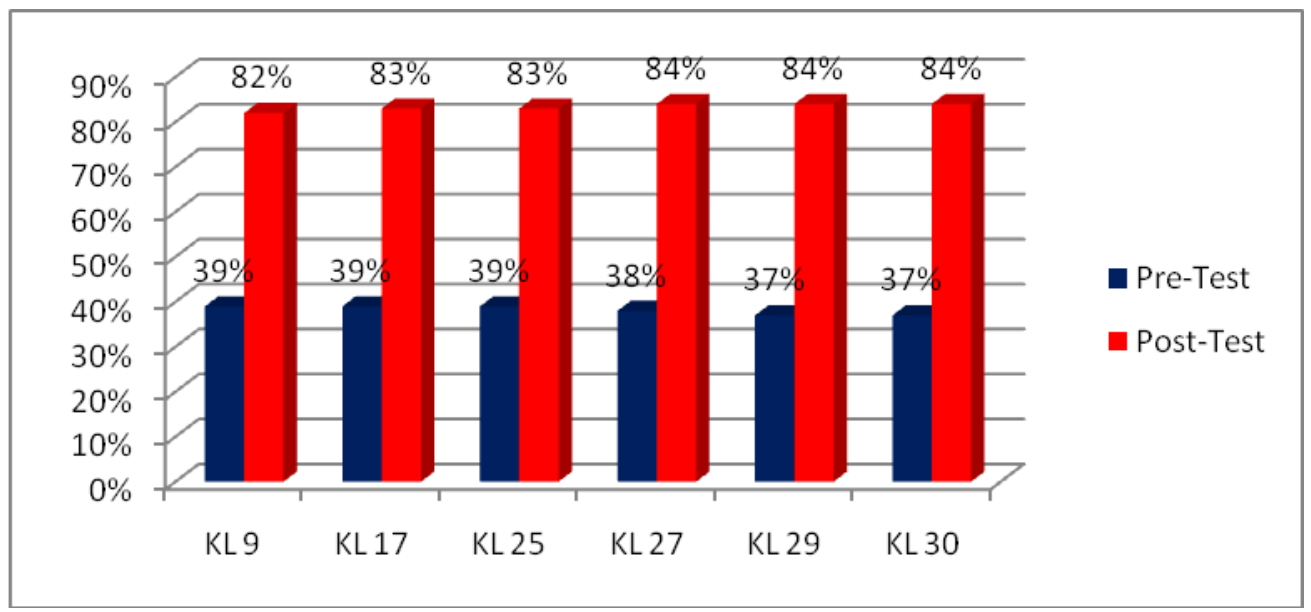


Berdasarkan gambar 1 diatas dapat dilihat bahwa masing-masing konseli kelompok treatment sebelum diberikan konseling kelompok dengan menggunakan teknik role playing berada dalam kategori self confidence rendah. Setelah diberikan Konseling kelompok teknik role playing mengalami peningkatan self confidence yang ditandai dengan meningkatnya prosentasi skala self confidence. Seperti Kl 9 dengan kategori sangat tinggi dengan prosentasi 39\% menjadi 82\%, K1 17 dengan kategori sangat tinggi dengan prosentasi $39 \%$ menjadi $83 \%$, Kl 25 dengan kategori sangat tinggi dengan prosentasi $39 \%$ menjadi 83\%, Kl 27 dengan kategori sangat tinggi dengan prosentasi 38\% menjadi 84\%, Kl 29 dengan kategori sangat tinggi dengan prosentasi $37 \%$ menjadi $84 \%$, Kl 30 dengan kategori rendah dengan prosentasi $37 \%$ menjadi $84 \%$.

Gambar 2

Diagram Batang Perbedaan Pre Test dan Post test Kelompok Kontrol

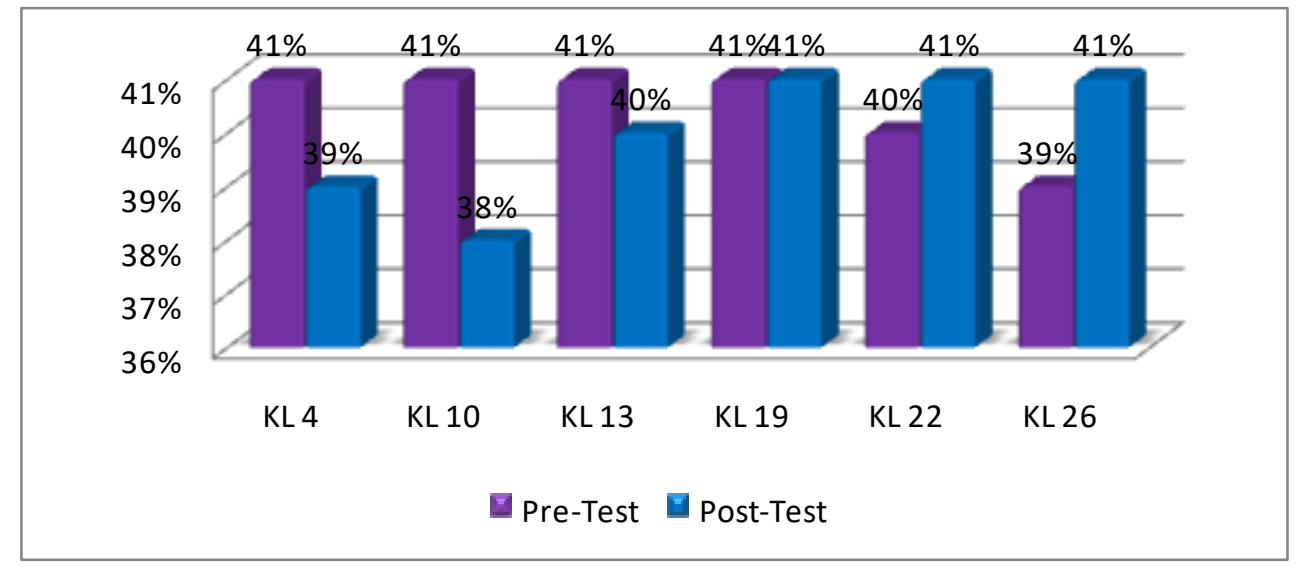

Berdasarkan gambar 2 diatas dapat dilihat bahwa masing-masing konseli pada kelompok kontrol hampir tidak ada menunjukkan perbedaan nilai prosentasi yang besar. Seperti K1 4 dengan kategori rendah dengan prosentasi $41 \%$ menurun menjadi 39\%, Kl 10 dengan kategori rendah dengan prosentasi $41 \%$ menurun menjadi 38\%, Kl 13 dengan kategori rendah dengan prosentasi $41 \%$ menurun menjadi 40\%, Kl 19 dengan kategori rendah dengan prosentasi $41 \%$ menjadi tetap 41\%, Kl 22 dengan kategori rendah dengan prosentasi $40 \%$ menjadi $41 \%, \mathrm{Kl}$ 26 dengan kategori rendah dengan prosentasi $39 \%$ menjadi $41 \%$.

Untuk pengujian hipotesa kerja dalam penelitian : 
Ha : Adanya perbedaan tingkat prosentasi self confidence siswa sebelum diberikan teknik role playing dan sesudah diberikan teknik role playing.

Ho : Tidak ada perbedaan tingkat prosentasi self confidence siswa sebelum diberikan teknik role playing dan sesudah diberikan teknik role playing.

Untuk mengidentifikasi adanya perbedaan prosentasi self confidence ketika sebelum dan sesudah konseling, dapat diketahui dari hasil pengujian dengan $\mathbf{U j i} \mathbf{t}$ test (Analisis t-test) secara manual yang disajikan sebagai berikut:

Tabel 2

Persiapan Kerja Perhitungan T Test

\begin{tabular}{|l|l|l|l|l|l|l|l|l|l|}
\hline \multicolumn{4}{|l|}{ Kelompok Treatment } & \multicolumn{6}{l|}{ Kelompok Kontrol } \\
\hline Subjek & $\begin{array}{l}\text { Pre } \\
\text { Test }\end{array}$ & $\begin{array}{l}\text { Post } \\
\text { Test }\end{array}$ & $\begin{array}{l}\text { Beda } \\
\left(\mathbf{X}_{1}\right)\end{array}$ & $\mathbf{x}_{\mathbf{1}}{ }^{2}$ & Subjek & $\begin{array}{l}\text { Pre } \\
\text { test }\end{array}$ & $\begin{array}{l}\text { Post } \\
\text { Test }\end{array}$ & $\begin{array}{l}\text { Beda } \\
\left(\mathbf{X}_{2}\right)\end{array}$ & $\mathbf{x}_{2}{ }^{2}$ \\
\hline KI 9 & 55 & 117 & 62 & 3844 & KI 4 & 58 & 54 & -4 & 16 \\
\hline KI 17 & 54 & 116 & 62 & 3844 & KI 10 & 58 & 53 & -5 & 25 \\
\hline KI 25 & 54 & 115 & 61 & 3721 & KI 13 & 57 & 56 & -1 & 1 \\
\hline KI 27 & 53 & 117 & 64 & 4096 & KI 19 & 57 & 58 & 1 & 1 \\
\hline KI 29 & 52 & 118 & 66 & 4356 & KI 22 & 56 & 57 & 1 & 1 \\
\hline KI 30 & 52 & 116 & 64 & 4096 & KI 26 & 55 & 57 & 2 & 4 \\
\hline $\mathrm{n}_{1}=6$ & 320 & 699 & 379 & 23957 & $\mathrm{n}_{2}=6$ & 341 & 335 & -6 & 48 \\
\hline
\end{tabular}

Untuk mendapatkan nilai rata-rata $\left(\overline{\mathrm{X}}_{1}\right.$ dan $\left.\overline{\mathrm{X}}_{2}\right)$ pada kelompok Treatment dan Kontrol :

$$
\begin{aligned}
& \sum X_{1}=397 \\
& \bar{X}_{1}=\frac{379}{6}=63,2
\end{aligned}
$$

$$
\begin{aligned}
& \sum \mathrm{X}_{2}=-6 \\
& \overline{\mathrm{X}}_{2}=\frac{-6}{6}=-1
\end{aligned}
$$

Untuk mendapatkan varian

$\left(\mathrm{S}_{1}^{2}\right.$ dan $\left.\mathrm{S}_{2}{ }^{2}\right)$ pada kelompok Treatment dan Kontrol :

$$
\begin{aligned}
\Sigma \mathrm{X}_{1}{ }^{2} & =23957 \\
\mathrm{~S}^{2} & =\frac{\Sigma \mathrm{X}_{1}{ }^{2}}{\mathrm{n}_{1}}-\overline{\overline{\mathrm{X}}}_{1}^{2} \\
= & \frac{23957}{6}-63,2
\end{aligned}
$$




$$
\begin{aligned}
= & 3992,8-3994,24 \\
= & -1,44 \\
\Sigma \mathrm{X} 2^{2} & =48 \\
\mathrm{~S}_{2}{ }^{2} & =\frac{\Sigma \mathrm{X}_{1}{ }^{2}}{\mathrm{n}_{2}}-\overline{\mathrm{X}}_{2}^{2} \\
& =\frac{48}{6}-(-1) \\
& =8-1 \\
& =7
\end{aligned}
$$

Dimasukkan ke rumus t-test:

$$
\begin{aligned}
& \mathrm{t}=\frac{\overline{\mathrm{X}}_{1}-\overline{\mathrm{X}}_{2}}{\sqrt{\frac{\left(\mathrm{n}_{1}-1\right) \mathrm{s}_{1}^{2}+\left(\mathrm{n}_{2}-1\right) \mathrm{s}_{2}^{2}}{\mathrm{n}_{1}+\mathrm{n}_{2}-2}\left(\frac{1}{\mathrm{n}_{1}}+\frac{1}{\mathrm{n}_{2}}\right)}} \\
& t=\frac{63,2-(-1)}{\frac{\sqrt{(6-1) \cdot(-1,44)+(6-1) \cdot(7)}}{6+6-1}\left(\frac{1}{6}+\frac{1}{6}\right)} \\
& =\frac{62,2}{\frac{\sqrt{(-7,2)+(35)}}{10}\left(\frac{2}{6}\right)} \\
& =\frac{62,2}{\frac{\sqrt{42,2}}{10}\left(\frac{2}{6}\right)} \\
& =\frac{62,2}{\sqrt{1,41}}=\frac{62,2}{1,2}=51,83
\end{aligned}
$$

Berdasarkan perhitungan manual dengan menggunakan analisis t-test di atas mendapatkan hasil $t_{\text {hit }}=51,83$, dengan harga $\mathrm{t}_{\mathrm{tab}}(\mathrm{d} . \mathrm{b})=\mathrm{n}_{1}+\mathrm{n}_{2}-2=10$, dengan taraf kepercayaan $95 \%$ yaitu $\alpha=$ 0,05. Dari data yang didapatkan secara manual dengan syarat agar diterima atau ditolak adalah sebagai berikut :

Apabila $\mathrm{t}_{\text {hitung }}>\mathrm{t}_{\text {tabal }}$ maka Ho ditolak. Sedangkan apabila $\mathrm{t}_{\text {hitung }}<\mathrm{t}_{\text {tabel }}$ maka Ho diterima.

Dari data yang didapatkan $\mathrm{t}_{\text {hitung }}>\mathrm{t}_{\mathrm{i}}\left(\begin{array}{ll}51,83 & 2,228) \text { maka }\end{array}\right.$

Ho ditolak. Jadi keputusan yang diambil menggunakan $\mathrm{Ha}$, yaitu Adanya perbedaan prosentasi self confidence siswa sebelum dan sesudah diberikan teknik role playing.

Hasil penelitian menunjukkan bahwa teknik role playing efektif meningkatkan self confidence siswa disekolah yang ditandai dengan adanya peningkatan prosentasi skala self confidence perbedaan siswa sebelum diberikan teknik role playing dan sesudah diberikan teknik role playing. Perubahan peningkatan prosentasi skala self confidence ini nampak bahwa sebelum adanya perlakuan self confidence siswa dalam kategori rendah, setelah diberikan perlakuan dengan 
teknik role playing prosentasi self confidence siswa meningkat kedalam kategori sangat tinggi.

Secara khusus temuan lain dalam penelitian ini adalah terdapatnya subjek KI 29 (SS) dan subjek KI 30 (SN) yang memperoleh tingkat perbedaan prosentasi self confidence siswa sebelum diberikan teknik role playing dan sesudah diberikan teknik role playing, prosentasi self confidence cenderung meningkat paling besar, yaitu berada dalam kategori sangat tinggi sebesar $84 \%$.

Salah satu faktor keberhasilan teknik role playing ini yakni siswa itu sendiri (internal) yaitu kecenderungan minat yang tinggi untuk berusaha menigkatkan self confidence. Siswa memiliki keyakinan bahwa konselor mampu membantunya sehingga konseli dengan sungguh-sungguh mengikuti kegiatan konseling dengan teknik role playing dan benar-benar melaksanakan prosedur yang telah dibuat. Peningkatan self confidence mulai nampak pada tahap 2, konseli sudah mulai bisa tampil dengan self confidence yang baik seperti berdiskusi dan berkomunikasi dengan teman dan mampu tampil dimuka kelas.

Peningkatan self confidence kedua dialami KI $27(\mathrm{NH})$ yaitu berada dalam kategori sangat tinggi sebesar $84 \%$ sebelumnya berada dalam kategori rendah dengan prosentasi self confidence $38 \%$. Hal ini dipengaruhi karena saat melaksanakan konseling konseli bersemangat dan berusaha melaksanakan teknik tersebut. KI 17 (MR) dengan peningkatan prosentasi self confidence sebesar $83 \%$ yaitu berada dalam kategori sangat tinggi. KI 25 (RP) dengan prosentasi self confidence $83 \%$ yaitu berada dalam kategori sangat tinggi. dan KI 9 (IL) dengan prosentasi self confidence $82 \%$ yaitu berada dalam kategori sangat tinggi. Dengan kesimpulan semua kelompok treatment mengalami peningkatan self confidence setelah diberikan teknik role playing dalam kategori sangat tinggi.

Siswa pada kelompok kontrol masing-masing konseli pada kelompok kontrol hampir tidak ada menunjukkan perbedaan nilai rata-rata dan prosentasi yang besar. Seperti Kl 4 (AW) dengan kategori rendah dengan prosentasi $41 \%$ menjadi 39\%, Kl 10 (JA) dengan kategori rendah dengan prosentasi $41 \%$ menjadi 38\%, Kl 13 (MR) dengan kategori rendah dengan prosentasi $41 \%$ menjadi 40\%, Kl 19 (NH) dengan kategori rendah dengan prosentasi $41 \%$ menjadi 41\%, Kl 22 (PD) dengan 
kategori rendah dengan prosentasi $40 \%$ menjadi 41\%, Kl 26 (RS) dengan kategori rendah dengan prosentasi 39\% menjadi $41 \%$. Semua kelompok kontrol berada dalam kategori rendah. Masalah self confidence yang paling dominan dihadapi oleh konseli yaitu rasa takut/khwatiran terhadap penolakan/kritikan, sulit menerima realita diri dan pesimis.

Adapun proses teknik role playing dipengaruhi adanya hambatan-hambatan baik dari koselor maupun konseli. Hambatan dari konselor berupa konselor belum dapat sepenuhnya menciptakan suasana yang nyaman dan enjoy pada saat memberikan teknik pada tahap I. Sedangkan, hambatan dari konseli adalah konseli tidak fokus dan kurang sungguh-sungguh dengan apa yang diberikan pada saat pelaksanaan konseling tersebut.

Adapun cara konselor dalam mengatasi hambatan-hambatan tersebut yaitu dengan cara memberikan motivasi kepada konseli bahwa dengan mengikuti teknik role playing dengan sungguhsungguh akan membantu meningkatkan self confidence.

Berdasarkan penjelasan diatas dapat disimpulkan untuk meningkatkan self confidence, dipengaruhi oleh faktor internal (dalam diri) dan faktor eksternal (lingkungan). Ini berarti individu harus berusaha untuk memelihara keseimbangan yang wajar atau memiliki hubungan yang humoris antara tuntutan internal dan eksternal.

Dari hasil pembahasan teknik role playing diatas, secara umum dapat dikatakan bahwa teknik role playing efektif untuk meningkatkan self confidence siswa, yang ditandai dengan meningkatnya prosentasi skala self confidence pada saat sebelum konseling dan setelah konseling.

Hal ini juga ditunjukkan dari hasil skala self confidence setiap konseli, yang dimana pada awalnya berdasarkan hasil pre-test memiliki tingkat self confidence dalam kategori rendah setelah diberikan teknik role playing menunjukkan tingkat self confidence pada kategori sangat tinggi.

Hasil yang sama juga dapat dilihat dari hasil penelitian yang relevan oleh (Purwitasari, Wahyu Indriani. 2008: 1) penerapan teknik role playing signifikan mampu meningkatkan keaktifan, keantusiasan dan prestasi belajar.

Berdasarkan penjelasan diatas dapat disimpulkan teknik role playing efektif meningkatkan self confidence 
siswa dengan adanya bukti dari hasil penelitian yang dipaparkan diatas.

\section{KESIMPULAN}

Berdasarkan hasil penelitian ini, maka dapat disimpulkan sebagai berikut:

1. Sebelum diberikan teknik role playing prosentasi self confidence rata-rata sebesar $38,2 \%$ dalam kategori rendah.

2. Setelah diberikan perlakuan menggunakan teknik role playing prosentasi self confidence rata-rata mengalami peningkatan menjadi $83,3 \%$ dalam kategori sangat tinggi.

3. Dari perhitungan Analisis t-test menunjukkan $t_{\text {hit }} 51,83>\mathrm{t}_{\mathrm{tab}} 2,228$ dengan taraf kepercayaan $95 \%$. Dengan demikian dapat disimpulkan bahwa: "teknik role playing efektif dalam meningkatkan self confidence siswa, yang ditandai dengan meningkatnya skala self confidence siswa.

\section{Saran-Saran}

Selama proses penelitian ini berlangsung ada beberapa hal yang menjadi catatan peneliti. Catatan ini menjadi hal yang perlu diperhatikan sekaligus sebagai saran.
1. Guru Mata Pelajaran

Guru mata pelajaran hendaknya bisa menggunakan teknik role playing dalam kegiatan belajar mengajar agar dapat membantu meningkatkan self confidence siswa dikelas.

2. Konselor Sekolah

Penggunaan teknik role playing dapat digunakan sebagai salah satu alternatif dalam meningkatkan self confidence siswa. Karena dengan penggunaan teknik role playing yang telah dilakukan peneliti pencapaian peningkatan self confidence siswa secara keseluruhan terbukti efektif meningkatkan self confidence siswa.

\section{DAFTAR PUSTAKA}

Antika, Rindi. 2011. Efektivitas Drama dalam Meningkatkan Kepercayaan Diri pada Anak Prasekolah, (Online), No.1 (file:///C:/Documents and Settings/user/My Documents/Jurnal Lengkap Kepercayaan Diri, diaskes 15 Sebtember 2012)

Arikunto, Suharsimi. 2006. Prosedur Penelitian Suatu Pendekatan Praktik. Jakarta: Rineka Cipta.

Hakim, Thursan. 2002. Mengatasi Rasa Tidak Percaya Diri. Jakarta: Puspa Swara. 
Hambly, Kenneth. 1995. Bagaimana Meningkatkan Rasa Percaya Diri. Jakarta: Arcan.

Hartanti, Ertin Puji. 2005. Keefektifan Kelompok Behavioral Terhadap Peningkatan Kepercayaan Diri Siswa. (Online), No 1 ( file:///C:/Documents and Settings/user/My Documents/Jurnal Lengkap Kepercayaan Diri, diaskes 5 Desember 2011)

Natawidjaja, Rocman. 2009. Konseling Kelompok Konsep Dasar dan Pendkatan. Bandung: Rizki Press.

Purwitasari, Wahyu Indriani. 2008. Penerapan metode pembelajaran role playing untuk meningkatkan keaktifan, keantusiasan, dan prestasi belajar pada mata pelajaran Ilmu Pengetahuan Sosial , ( Online), No 1, (file:///C:/Documents\%20and\%20 Settings/user/My\%20Documents/J urnal\%20Lengkap\%20Teknik\%20 Role\%20Playing/Lengkap/Wahyu \%20Indryana.htm, diaskes 10 Desember 2011)

Rohayati, Iceu. 2010. Program Bimbingan Teman Sebaya untuk Meningkatkan Percaya Diri Siswa. ( Online), No 1, ( file:///C:/Documents and Settings/user/My Documents/Jurnal Lengkap Kepercayaan Diri, diaskes 5 Desember 2011)

Sanjaya, Wina. 2009. Strategi Pembelajaran Berorientasi Standar Proses Pendidikan. Jakarta: Kencana.

Seran, Elina Yunutha. 2011. Dampak Penerapan Metode Role Playing Terhadap

Peningkatan
Kemampuan Berfikir Kritis dan Kepekaan Sosial Siswa, (Online), No 1. (file:///C:/Documents and Settings/user/My

Documents/Jurnal Lengkap Kepercayaan Diri, diaskes 15 Sebtember 2012)

Sugiyono. 2011. Metode Penelitian Kuantitatif Kualitatif dan $R \& D$. Jakarta: Alfabeta

Sudjana, Nana. 2010. Dasar-Dasar Proses Belajar Mengajar. Bandung: Sinar Baru Algesindo.

Suhardita, Kadek . 2010. Efektivitas Penggunaan Teknik Permainan Dalam Bimbingan Kelompok untuk Meningkatkan Percaya Diri Siswa. ( Online), No1,(file:///C:/Documents\% 20an d\% 20Settings/user/My\% 20Docu ments/Jurnal\% 20Lengkap\% 20 Kepercayaan \% 20Diri/PD.htm, diaskes 5 Desember 2011).

Widiawati, Ririn. 2010. Penerapan Pembelajaran Aktif Role Playing dengan SD Interaktif untuk Meningkatkan Motivasi Belajar Siswa, ( Online), No. 1, (file:///C:/Documents and Settings/user/My

Documents/Jurnal Lengkap Kepercayaan Diri, diaskes 10 Desember 2011).

Yuniarti, Yesi, 2010. Penggunaan KonselingRasional Emotif untuk Meningkatkan Rasa Percaya Diri Siswa, (Online): No 1, (file:///C:/Documents and Settings/user/My

Documents/Jurnal Lengkap Kepercayaan Diri, diaskes 15 Sebtember 2012) 